\title{
Benthic fluxes of copper, complexing ligands and thiol compounds in shallow lagoon waters
}

\author{
Conrad S. Chapman ${ }^{\mathrm{a}}$, Gabriele Capodaglio ${ }^{\mathrm{b}}$, Clara Turetta ${ }^{\mathrm{c}}$, Constant M.G. van den Berg ${ }^{\mathrm{a}, *}$ \\ ${ }^{a}$ Department of Earth and Ocean Sciences, University of Liverpool, Brownlow Street, Liverpool L69 3GP, UK \\ ${ }^{\mathrm{b}}$ University Ca' Foscari, Venice, Italy \\ ${ }^{\mathrm{c}}$ IDPA-CNR, Venice, Italy
}

\section{A R T I C L E I N F O}

\section{Article history:}

Received 17 April 2008

Received in revised form 29 July 2008

Accepted 30 July 2008

\section{Keywords:}

Heavy metals

Speciation

Ligands

Thiols

Benthic flux

Salt marsh

Venice lagoon

\begin{abstract}
A B S T R A C T
Benthic fluxes of copper, copper complexing ligands and thiol compounds in the shallow waters of Venice Lagoon (Italy) were determined using benthic chambers and compared to porewater concentrations to confirm their origin. Benthic copper fluxes were small due to small concentration differences between the porewaters and the overlying water, and the equilibrium concentration was the same at both sites, suggesting that the sediments acted to buffer the copper concentration. Thiol fluxes were $\sim 10 \times$ greater at 50-60 pmol cm $\mathrm{cm}^{-2} \mathrm{~h}^{-1}$, at the two sites. Porewater measurements demonstrated that the sediments were an important source of the thiols to the overlying waters. The overlying waters were found to contain at least two ligands, a strong one, L1 ( $\left.\log \mathrm{K}_{\mathrm{CuL} 1}^{\prime}=14.2\right)$ and a weaker one, $\mathrm{L}_{2}\left(\log \mathrm{K}_{\mathrm{CuL2}}^{\prime}=12.5\right)$. The concentration of $\mathrm{L} 1$ remained relatively constant during the incubation and similar to that of copper, whereas that of L2 was in great excess of copper, its concentration balanced by porewater releases and breakdown, probably due to uptake by microorganisms, similar to that of the thiol compounds. Similarity of the thiol and L2 concentrations and similar complex stability with copper suggest that L2 was dominated by the thiols. The free copper concentration ([Cú]) in the Lagoon waters was lowered by a factor of $10^{5}$ as a result of the organic complexation.
\end{abstract}

(c) 2008 Elsevier Ltd. All rights reserved.

\section{Introduction}

Sediments can act as a source of copper (Klinkhammer, 1980), copper complexing ligands (Skrabal et al., 2000), sulfur species and thiol compounds (Luther III et al., 1986). Metal complexing ligands (Croot et al., 2000; Moffett and Brand, 1996) and thiol compounds are also known to be released by marine phytoplankton (Dupont and Ahner, 2005; Leal et al., 1999) into surface waters. Specific thiols like glutathione have been found in oceanic (Dupont et al., 2006; Le Gall and van den Berg, 1998) and estuarine (Tang et al., 2004) waters. As thiol compounds form stable complexes with copper(I) (Leal and Van den Berg, 1998) it is likely that the thiols are part of the pool of copper complexing ligands in natural waters and could play a role in controlling the bioactivity and biogeochemistry of copper.

In this study we investigated whether benthic interactions are an important source for thiols, copper and copper-binding ligands in shallow surface waters as occurring in lagoons and salt marshes. Venice Lagoon (Italy) was selected for this study as it is an extensive, shallow lagoon, with salt marshes on the boundaries. Benthic interactions are likely to be relatively important to its water com-

\footnotetext{
* Corresponding author. Tel.: +44 1517944096.

E-mail address: vandenberg@liv.ac.uk (C.M.G. van den Berg).
}

position due to a shallow water depth of typically $1 \mathrm{~m}$. Benthic fluxes were determined by placing large benthic chambers on the sediments and following changes in the water composition as a function of time. Porewaters were collected from sediment cores to identify the source of the thiols and copper, and the concentration difference with the overlying water was used to estimate comparative thiol fluxes.

\section{Materials and Methods}

\subsection{Instrumentation and reagents}

Voltammetric equipment was a $\mu$ Autolab potentiostat attached to a Metrohm VA 663 electrode stand and controlled by a personal computer. The working electrode was a hanging mercury drop electrode (HMDE), the reference electrode was double junction, $\mathrm{Ag} / \mathrm{AgCl}, 3 \mathrm{M} \mathrm{KCl}$ and the counter electrode was a glassy carbon rod.

Water used for dilutions was obtained from a Milli-Q (MQ) system. $\mathrm{HCl}$ and $\mathrm{NH}_{3}$ were purified by sub-boiling distillation on a quartz condenser. Copper standards were prepared by dilution of atomic adsorption standards (Spectrosol, BDH) and acidified to $\mathrm{pH} 2.2$ using $11 \mathrm{M} \mathrm{HCl}$. Stock solutions of 0.01 salicylaldoxime (SA) $(\mathrm{BDH})$ were prepared in $0.1 \mathrm{M} \mathrm{HCl}$. 


\subsection{Speciation}

Copper, copper complexing ligands (Campos and van den Berg, 1994) and copper-thiol interactions (Leal and Van den Berg, 1998) were determined by cathodic stripping voltammetry (CSV). Copper complexing capacity titrations were at pH 7.8 (NBS scale), using $0.01 \mathrm{M}$ HEPES buffer, diluted from $1 \mathrm{M}$ HEPES (N-2 hydroxyethylpiperazine-N'-2 ethanesulfonic acid, Merck) and $0.55 \mathrm{M} \mathrm{NaOH}$, using ligand competition against $2 \mu \mathrm{M}$ SA (Campos and van den Berg, 1994). Reactive copper is part of the total dissolved copper which is bound by the added SA, which is a function of the competition between the added SA and the natural ligand. The reactive copper concentration ([ $\left.\mathrm{Cu}_{\text {reactive }}\right]$ ) was determined by CSV after deposition at $-0.1 \mathrm{~V}$, deposition time $90 \mathrm{~s}$ and the scan used the square-wave mode. Uncalibrated reactive copper concentrations (peak heights) were used to fit $\left[\mathrm{Cu}_{\text {reactive }}\right] /[\mathrm{CuL}]$ as a function of $\left[\mathrm{Cu}_{\text {reactive }}\right]$; a linear least squares regression was used unless curvature of a plot of $\left[\mathrm{Cu}_{\text {reactive }}\right] /[\mathrm{CuL}]$ as a function of $\left[\mathrm{Cu}_{\text {reactive }}\right]$ showed the presence of more ligands, which were then fitted using iterative, linear, least-squares regressions of the data. The sensitivity was corrected for the degree of unsaturation of the ligands with copper at the end of the titrations(Leal and Van den Berg, 1998; Turoczy and Sherwood, 1997). The uncertainties in the values for the ligand concentrations and stability constants were calculated from the standard deviation of the least-squares regressions.

Samples used for total dissolved copper were acidified to $\mathrm{pH} 2.5$ and UV-digested for $1 \mathrm{~h}$ in acid cleaned silica tubes, prior to CSV using $30 \mu \mathrm{M}$ SA at $\mathrm{pH} 8.3$ using $10 \mathrm{mM}$ borate $\mathrm{pH}$ buffer. The deposition potential was $-1.1 \mathrm{~V}$, the re-oxidation potential $-0.1 \mathrm{~V}$ and the CSV scan was in a negative direction using the square-wave modulation. The sensitivity was calibrated for each sample by standard additions of copper.

Reactive thiol concentrations were determined by CSV as before (Leal et al., 1999). Voltammetric parameters were as for reactive copper with calibration against glutathione which was found to behave similarly to the unknown thiol species. Our method differed from that used before in that the peak height of the total thiol concentration $\left(I_{\max }\right)$ was determined after addition of $100 \mu \mathrm{M}$ EDTA to free any thiols bound by copper and other metals by lowering the, free, ionic metal concentrations. The peak height of the reactive thiol species was measured during the complexing ligand titrations along with reactive copper, and used to compute conditional stability constants of the copper thiol complexes (Laglera and van den Berg, 2003). Stock solutions of glutathione, thioacetamide, thiourea, cysteine (BDH) and 3-mercaptopropanoic acid (Fluka) were prepared freshly before use by dissolution in MQ.

\subsection{Study sites}

Venice Lagoon, Italy, lies on the northern Adriatic coast and consists of salt marshes and shallow waters. It is constituted of three main basins and several sub-basins. During the $1960 \mathrm{~s}$ and $1970 \mathrm{~s}$ it was subjected to sizable anthropogenic inputs that have gradually impaired the quality of the lagoon ecosystem (Pavoni et al., 1987). Significant amounts of these pollutants, both organic and inorganic, have accumulated in the sediments and may constitute a potential secondary source of contaminants. The water exchange rate is $140 \mathrm{~km}^{3} \mathrm{yr}^{-1}$, it has an area of $549 \mathrm{~km}^{2}$ and an average depth of $1 \mathrm{~m}$, causing a residence time of the water of about one day, but this can increase to three days in areas of lower dynamics. In remote parts of the lagoon, atmospheric deposition of contaminants is thought to dominate (Cochran et al., 1998) but run-off is the main source near an industrial area (Donazzolo et al., 1984).

Two sites were studied, both in relatively contaminated waters: Tresse (Site 1), near the industrial area of Marghera, and Campalto (Site 2), near to an area with a history of solid waste disposal (Turetta et al., 2005) (Fig. 1). The experiment at Tresse was from 28 to 31 October 2002 and at Campalto from 25 to 27 May 2003; both started at 1:00 PM. The sediment from site 1 (the first $\mathrm{cm}$ ) had a mean organic carbon content of $0.4 \%$ and was classified as silt clay loam. The mean organic carbon concentration in the sediment of site 2 was $1.0 \%$ which was classified as silty clay.

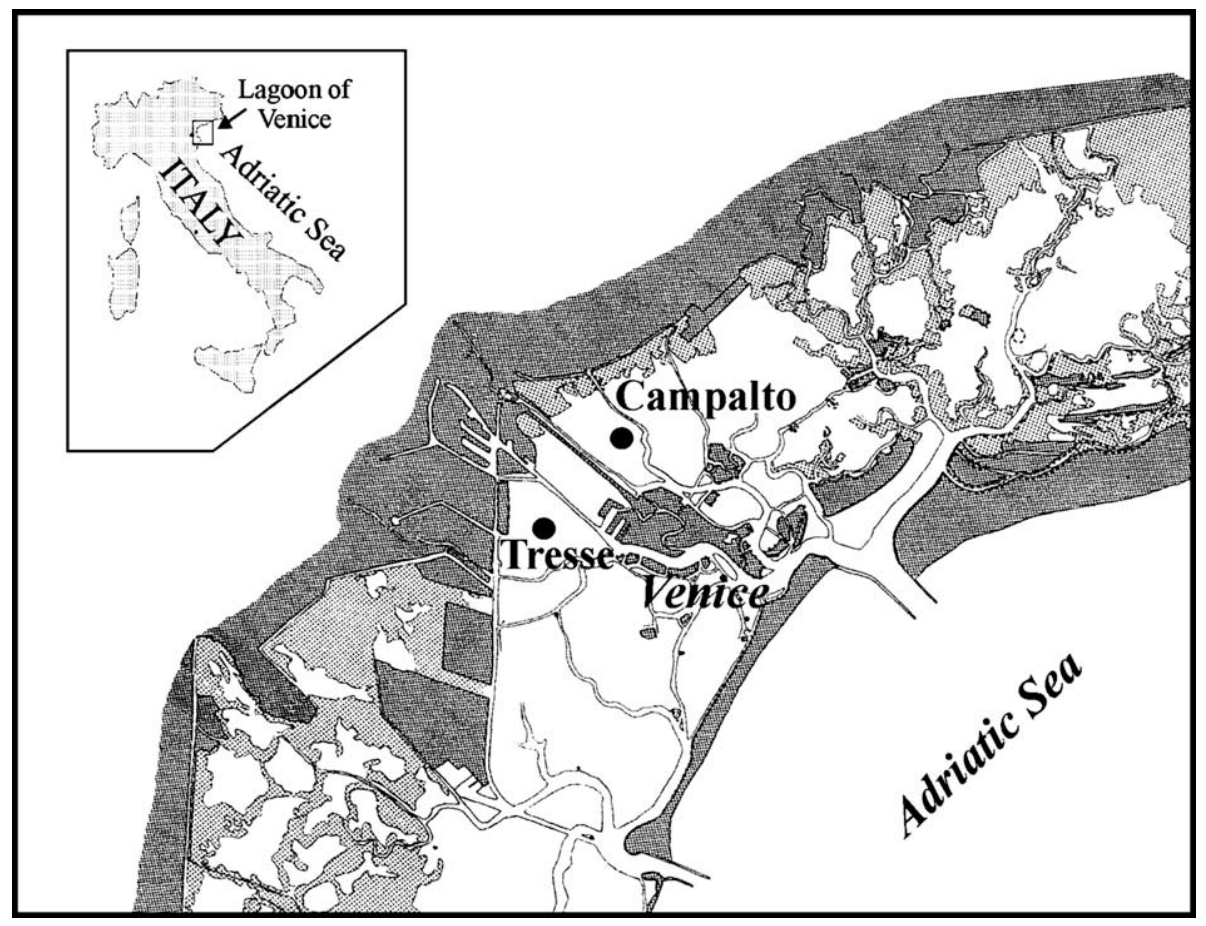

Fig. 1. Map showing the locations of the sample sites in Venice Lagoon, Italy. 


\subsection{Benthic chambers}

Benthic chambers were constructed at Venice University with a volume of $90 \mathrm{~L}$ with collapsible, polyethylene, sides to enable sample extraction without water exchange (Turetta et al., 2005). The chambers $(60 \mathrm{~cm} \times 60 \mathrm{~cm})$ had a water height of $25 \mathrm{~cm}$ and the water was mixed slowly by a paddle $\left(120 \mathrm{~cm}^{2}\right)$ rotating at $10 \mathrm{rpm}$. The stirring ensured mixing of the internal water in about 2 min with a diffusive boundary layer thickness of about $0.5 \mathrm{~mm}$ and a current speed close to the bottom of about $2 \mathrm{~cm} \mathrm{~s}^{-1}$, at which sediment resuspension should be minor (Tengberg et al., 2005). Samples were collected by battery operated peristaltic pump. Oxygen, $\mathrm{pH}$, conductivity and temperature were monitored continuously using a multi-probe (YSI, model 556, Ohio, USA).

Water samples for metal analyses were collected every $3 \mathrm{~h}$ and for metal speciation at $9 \mathrm{~h}$ intervals. All samples were filtered using two-stage cartridge filters containing $0.45 \mu \mathrm{m}$ and $0.2 \mu \mathrm{m}$ membranes (Sartorius Sartobran 300) and collected in low density polyethylene (LDPE) bottles. Speciation samples were subsequently stored frozen and other samples were acidified. The sample bottles were cleaned by soaking sequentially in hot detergent and dilute $(2 \mathrm{M})$ acid and were stored partially filled with $0.01 \mathrm{M} \mathrm{HCl}$. The bottles were rinsed with water from the chamber before filling.

\subsection{Porewater sampling}

$30 \mathrm{~cm}$ box cores were collected from the sediments at the sampling sites (June 2003) using a piston corer. The cores were sealed and stored in a nitrogen-flushed box to maintain an oxygen-free atmosphere. The overlying water column was sampled at the same time. The cores were sliced at intervals of $0.5-2 \mathrm{~cm}$ with more detail at the top of the core. The slices were centrifuged to extract the porewater, which was quickly filtered under an inert atmosphere and frozen until analysis. Copper in the porewaters was determined by ICP-SFMS (inductively coupled plasma-sector field mass spectrometry) (Turetta et al., 2005).

\subsection{Calculation of the benthic flux from the benthic chamber data}

Benthic fluxes were calculated from the change in the concentrations as a function of time where each change was corrected for the volume change after sampling:

$\Delta \operatorname{mol} \Delta \mathrm{t}^{-1}=\left(\sum \operatorname{mol}_{i(r e m)}+\mathrm{mol}+i\right) \Delta \mathrm{t}_{i}^{-1}$

where $\Sigma \mathrm{mol}_{i(\mathrm{rem})}$ was the sum of the moles removed of the chamber as a result of sampling at time $\mathrm{i}, \Delta \mathrm{t}_{i}$ the time lapsed during time interval $i(\mathrm{~h})$, and $\mathrm{mol}_{i}$ was the actual number of moles in the chamber at time $i$. The values for $\Delta \mathrm{mol} \Delta \mathrm{t}^{-1}$ were used to calculate the flux, $F$ :

$F=\Delta \operatorname{mol} \Delta \mathrm{t}^{-1} A^{-1}$

where A was the sediment area $\left(\mathrm{cm}^{2}\right)$ covered by the chamber. The flux $\mathrm{F}$ (pmoles $\mathrm{cm}^{-2} \mathrm{~h}^{-1}$ ) was obtained by linear regression of the data.

\subsection{Calculation of the benthic flux from the gradient at the sediment/ water interface}

Estimates of the molecular diffusion of thiols across the sediment-water interface were calculated from the sediment/water gradient using the following equation (Berner, 1980):

$F_{d}=-D_{s} \delta C \delta x^{-1}$

where $F_{\mathrm{d}}=$ the diffusion flux of the species $\left(\mathrm{pmol} \mathrm{cm} \mathrm{cm}^{-2} \mathrm{~h}^{-1}\right), \mathrm{D}_{\mathrm{s}}=$ the diffusion coefficient of the species in sedimentary porewaters $\left(10^{-6} \mathrm{~cm}^{2} \mathrm{~s}^{-1}\right), \delta C \delta \mathrm{x}^{-1}=$ concentration gradient of the species across the sediment-water interface $\left(\mathrm{pmol} \mathrm{cm} \mathrm{cm}^{-4}\right)$, and where $x=$ $0.05 \mathrm{~cm}$ (diffusion boundary layer thickness) was set by the stirring rate in the chamber. Uncertainties in the fluxes were calculated from the standard deviation of the measured thiol concentrations. Differences in the composition of porewater from the top $0.5 \mathrm{~cm}$ of the sediment and from surface water from a depth of $\sim 20 \mathrm{~cm}$ (total water depth $\sim 1 \mathrm{~m}$ ) were used to establish the gradients.

The porewater diffusion coefficient $\left(D_{s}\right)$ was calculated using (Iversen and Jorgensen, 1993):

$D_{s}=D_{0}(1+n(1-\phi))^{-1}$

where parameter $\mathrm{n}$ depends on the type of sediment and the diffusing species: a value of 3 was selected as before for similar sediments (Iversen and Jorgensen, 1993). Changing $\mathrm{n}$ in the porosity range of the sample sites $(0.5-0.75)$ created differences of less than $10 \%$ in $D_{s}$ per unit of $n$. $D_{0}$ was the diffusion coefficient of the species at infinite dilution $\left(\mathrm{cm}^{2} \mathrm{~s}^{-1}\right.$ ) (Li and Gregory, 1974) and $\phi$ was the porosity of the sediment (\% volume/weight). The flux value included tortuosity (constrained diffusion) and molecular diffusion within the porewaters, but did not account for other processes such as adsorption, wave shear and bioturbation (Berner, 1980).

\section{Results and discussion}

\subsection{Temperature, oxygen and salinity}

The chambers were placed on the sediments, carefully pushed into the top of the sediments and then the cover was closed; the stirrer was started and the measurements were initiated. The chambers were fully submerged and the water depth was $\sim 1 \mathrm{~m}$. It is likely that the placing of the benthic chamber and the starting of the stirrer would have disturbed the original gradients across the sediment - water interface. However, this is an unavoidable problem with using benthic chambers. In this case any effects were minimized by using a large chamber which was open at the time of placing and by using a slow stirring rate. The absence of abrupt variability in the major parameters (oxygen, $\mathrm{pH}$ ) suggests that the water in the chamber had equilibrated within an hour, possibly minutes. The oxygen concentration in both chambers dropped to $\sim 94 \mu \mathrm{M} \mathrm{O}_{2}$ ( $\sim 30 \%$ air saturation) during the first 12-15 h (Fig. 2), after which it continued to drop more gradually at Tresse and became more or less constant at Campalto. The overall decrease was greatest at Campalto which started from a higher concentration of oxygen ( $219 \mu \mathrm{M} \mathrm{O}_{2}$ compared to $156 \mu \mathrm{M} \mathrm{O}$ at Tresse). The temperature variation in the chambers can be used as a measure of possible effects of solar radiation and from this it can be seen that the leveling off of the oxygen concentration at Campalto, and the slower drop at Tresse, coincided with daylight, indicating that further oxygen uptake was balanced by oxygen production by benthic or planktonic algae.

The pH dropped from 8 to 7.6 at Tresse and from 7.8 to 7.3 at Campalto presumably due to diffusion of $\mathrm{CO}_{2}$ out of the sediments, or bacterial activity in the chamber water itself. The drop in $\mathrm{pH}$ paralleled that in $\mathrm{O}_{2}$ which stabilized after $22 \mathrm{~h}$ at the Campalto site and gradually leveled off at Tresse (Fig. 2). The parallel behaviour of $\mathrm{O}_{2}$ and $\mathrm{CO}_{2}$ is consistent with the release of $\mathrm{CO}_{2}$ by heterotrophic organisms as they use oxygen, either in the benthic chamber itself or due to diffusion of $\mathrm{CO}_{2}$ from the sediments and $\mathrm{O}_{2}$ into the sediments. Dissolved organic carbon (DOC) showed comparatively small variability: at Tresse the decrease was from 160 at the beginning to $150 \mu \mathrm{M}$ carbon by the end of the experiment, and at Campalto from $\sim 600$ to $500 \mu \mathrm{M}$ carbon except for an outlier of $750 \mu \mathrm{M}$ carbon after $25 \mathrm{~h}$ (Manodori et al., 2006). The decreases in DOC in the benthic chambers were much less than those of dissolved oxygen indicating that the much larger varia- 

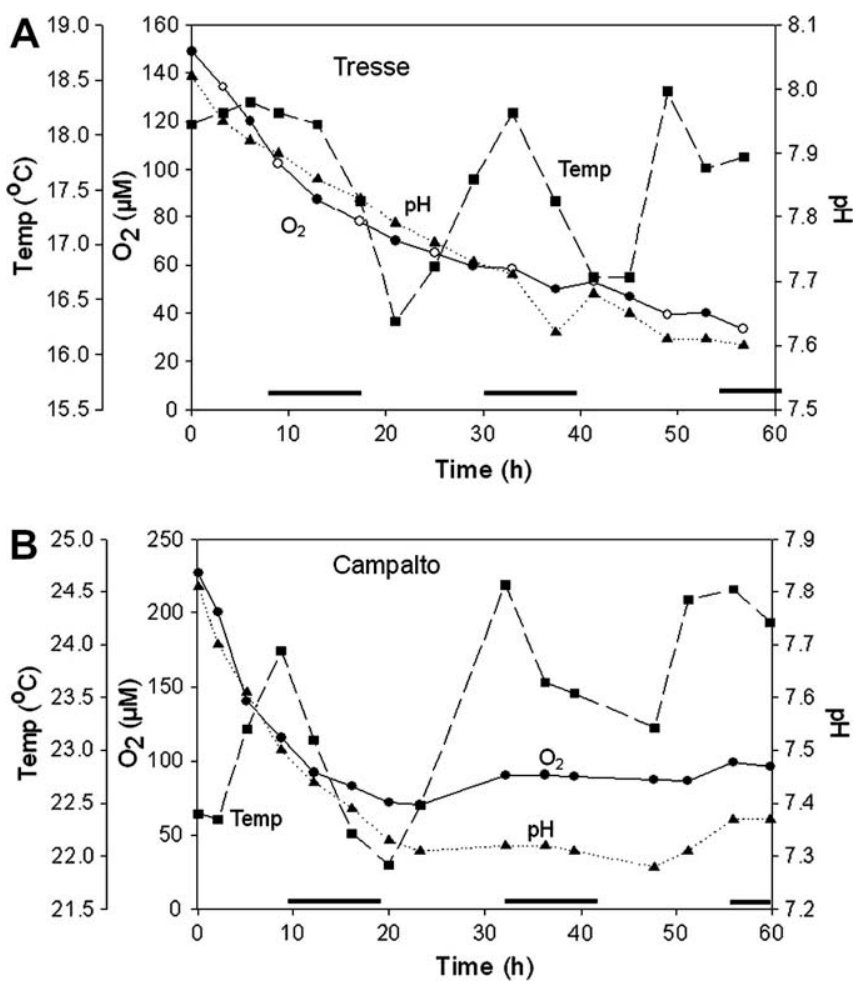

Fig. 2. Temperature, $\mathrm{pH}$ and dissolved oxygen $(\mu \mathrm{M})$, inside the benthic chambers during the experiments. A) Tresse: 28-31 October 2002 (salinity 29.4); B Campalto: 25-27 May 2003 (salinity 28.6). Solid black bars show night time hours.

tions in $\mathrm{O}_{2}$ and $\mathrm{CO}_{2}$ were not related to bulk breakdown of the DOC in the chamber but due to benthic processes.

The oxygen flux ( $\mathrm{nmol} \mathrm{cm} \mathrm{ch}^{-1}$ ), calculated from the change in the benthic chamber composition as a function of time, was -86 (negative means into the sediments) at Tresse and -163 at Campalto for the first $25 \mathrm{~h}$ of the experiment. These values are similar to oxygen fluxes found in other estuarine sediments; for instance, a flux of $-150 \mathrm{nmol} \mathrm{O}_{2} \mathrm{~cm}^{-2} \mathrm{~h}^{-1}$ has been found previously in estuarine sediments of sandy mud (Clavero et al., 1992). The oxygen flux decreased after the first $25 \mathrm{~h}$ to $\sim-23 \mathrm{nmol} \mathrm{cm}^{-2} \mathrm{~h}^{-1}$ at Tresse, and became insignificant at Campalto, as the chamber became equilibrated with the sediments and further oxygen decreases were offset by in situ oxygen production.

\subsection{Copper fluxes derived from the benthic chamber data}

The copper concentration in the chambers was initially greater at Tresse $(40 \mathrm{nM})$ than at Campalto $(14 \mathrm{nM})$ (Fig. 3). With time the concentrations converged to similar levels at the two sites: $\sim 24 \mathrm{nM}$ at Campalto and $\sim 19-24 \mathrm{nM}$ at Tresse, compared to outside chamber values of $40 \mathrm{nM}$ (Tresse) and $24 \mathrm{nM}$ (Campalto). Because of the greater than equilibrium concentration of copper in the water at Tresse station, the copper flux was negative, $-4.4 \pm 0.2 \mathrm{pmol} \mathrm{cm}^{-2} \mathrm{~h}^{-1}$, whereas it was positive $3.8 \pm 0.1 \mathrm{pmol}$ $\mathrm{cm}^{-2} \mathrm{~h}^{-1}$ at Campalto (out of the sediments).

It is possible that $19-24 \mathrm{nM} \mathrm{Cu}$ is the steady state level for copper in these waters, a balance of adsorption on particles, uptake by phytoplankton and other algae, releases or uptake from the sediments and possible interactions with strong complexing ligands. This steady state level (19-24 nM) is similar to levels of 8-21 nM found previously in the north of the lagoon (Martin et al., 1994). It is likely that the proximity of an industrial zone (Porto Maghera) near Tresse may have been the cause for the initially higher copper levels in the lagoon water at Tresse than at
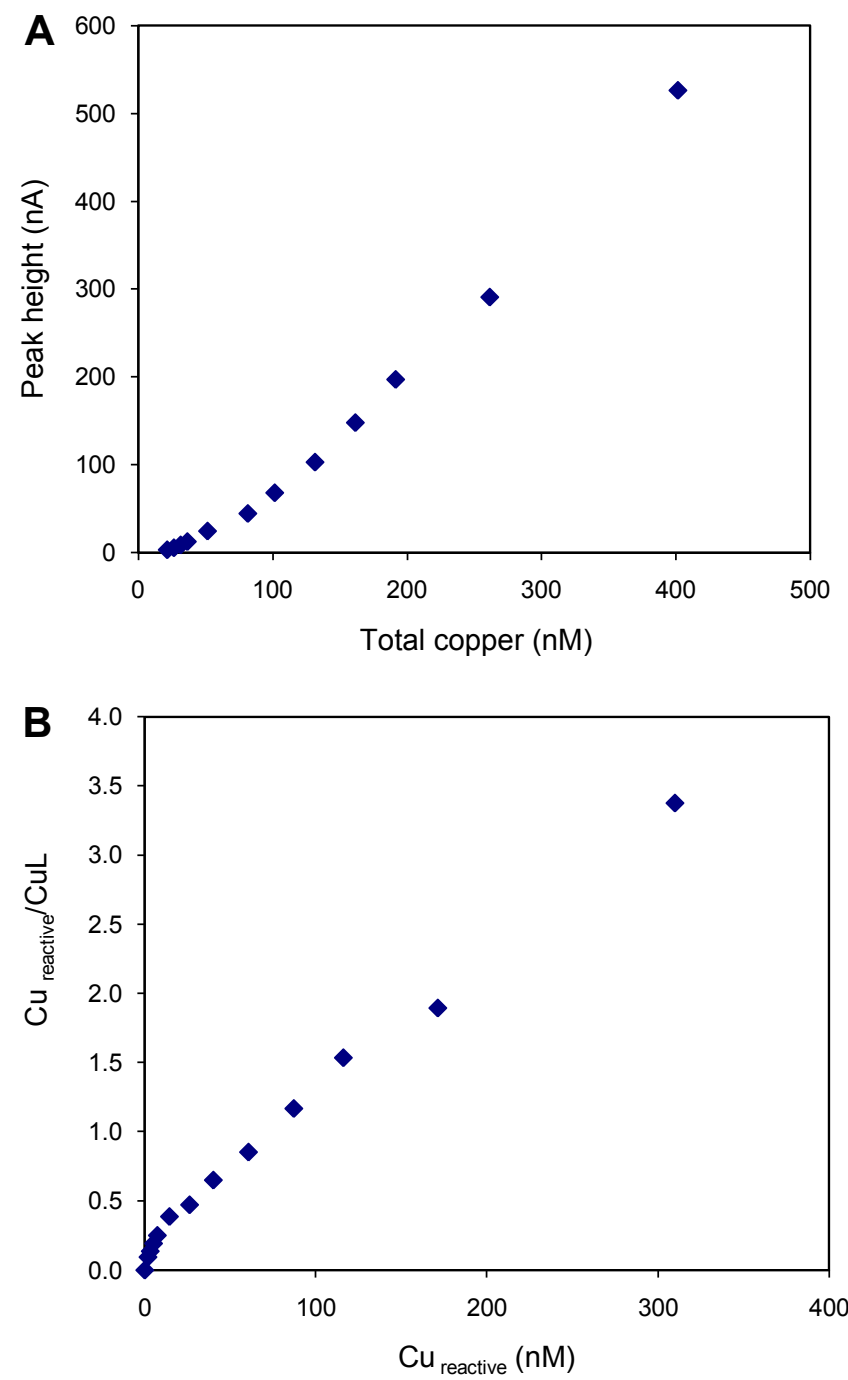

Fig. 3. Complexing capacity titration of copper in the presence of $2 \mu \mathrm{M}$ SA. (A) Curvature in the plot of reactive copper as a function of total copper showed the presence of complexing ligands; (B) linearization of the data: curvature shows the presence of at least two ligands. A good data fit was obtained to a two-ligand model.

Campalto. The steady state copper levels in the Venice Lagoon were greater than those $(2-15.5 \mathrm{nM})$ in San Diego Bay (Zirino et al., 1998), similar to those (10-25 nM), in the lagoons of Jacarepaguá, Rio de Janeiro, Brazil (Fernandes et al., 1994), and less than those (31-95 nM) in the Pom-Atasta Lagoon, Mexico (Vazquez et al., 1999), suggesting that, relative to other shallow lagoon waters, Venice Lagoon does not suffer from major contamination with copper.

\subsection{Organic copper complexing ligands}

Curvature in the linearised form of the speciation data showed that copper complexation was affected by more than one ligand (Fig. 3). A good fit of the data was obtained to a model containing two ligands at both stations: L1 and L2, with complex stabilities $\left(\log K_{\text {CuL1 }}^{\prime}\right.$ and $\log K_{\text {CuL2 }}^{\prime}$ ) of $14.2 \pm 0.5$ and $12.5 \pm 0.3$ respectively (Table 1 ). The overall $\alpha$-coefficient, $\alpha_{\text {CuL }}$, was $10^{6}$ (Table 1 ) predominantly as a result of complexation with $\mathrm{L} 1$, causing the free copper concentration to be low with $\mathrm{pCu}$ values of $13.7 \pm 0.2(\mathrm{pCu}=-\log$ $\left.\left[\mathrm{Cu}^{2+}\right]\right)$. These levels are well below where free copper affects marine microorganisms: for instance, cupric ion concentrations $>1 \mathrm{pM}$ are thought to influence cyanobacteria (Brand et al., 1986). 
Table 1

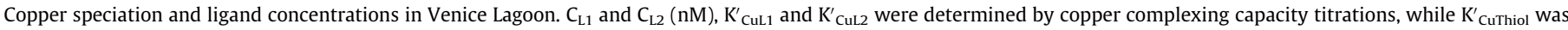

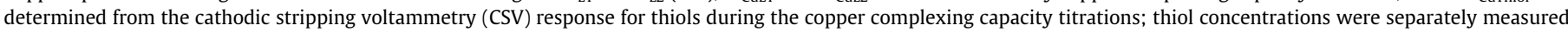
and are in glutathione equivalents. The standard deviation of the $\log K^{\prime}{ }_{\text {CuThiol }}$ values is $\pm 0.1(n=12)$.

\begin{tabular}{|c|c|c|c|c|c|c|c|c|c|}
\hline Site/time from start (h) & $\mathrm{C}_{\mathrm{Cu}}(\mathrm{nM})$ & $\mathrm{C}_{\mathrm{L} 1}(\mathrm{nM})$ & Log $K_{\text {CuL1 }}^{\prime}$ & $\mathrm{C}_{\mathrm{L} 2}(\mathrm{nM})$ & Log $K_{\text {CuL2 }}^{\prime}$ & $\mathrm{pCu}$ & $\log \alpha_{\mathrm{CuL}}$ & Thiols (nM) & Log $K_{\text {CuThiol }}^{\prime}$ \\
\hline Tresse/6 & 24.4 & $22.9 \pm 1.9$ & $14.8 \pm 0.6$ & $41 \pm 1$ & $12.8 \pm 0.1$ & 13.8 & 6.2 & 62 & 13.1 \\
\hline Tresse/17 & 23.0 & $17.3 \pm 2.2$ & $13.9 \pm 0.3$ & $41 \pm 4$ & $12.8 \pm 0.2$ & 13.3 & 5.6 & 77 & 13.0 \\
\hline Tresse/29 & 21.7 & $20.2 \pm 0.4$ & $14.7 \pm 0.1$ & $97 \pm 10$ & $12.4 \pm 0.1$ & 13.8 & 6.1 & 113 & 13.2 \\
\hline Tresse/41 & 19.1 & $13.7 \pm 0.5$ & $15.0 \pm 0.3$ & $116 \pm 1$ & $12.4 \pm 0.1$ & 13.7 & 6.0 & 120 & 13.3 \\
\hline Tresse/53 & 18.8 & $12.4 \pm 1.1$ & $14.3 \pm 0.4$ & $33 \pm 2$ & $13.0 \pm 0.2$ & 13.5 & 5.7 & 57 & 13.1 \\
\hline Campalto/2 & 16.5 & $15.1 \pm 4.0$ & $13.8 \pm 0.2$ & $122 \pm 2$ & $12.7 \pm 0.1$ & 13.9 & 5.9 & 97 & 13.3 \\
\hline Campalto/12 & 10.3 & $14.3 \pm 1.8$ & $13.7 \pm 0.1$ & $127 \pm 6$ & $12.6 \pm 0.1$ & 14.0 & 6.0 & 125 & 13.2 \\
\hline Campalto/23 & 13.9 & $17.7 \pm 2.1$ & $13.5 \pm 0.1$ & $168 \pm 14$ & $12.5 \pm 0.1$ & 13.8 & 5.9 & 152 & 13.4 \\
\hline Campalto/36 & 18.0 & $25.2 \pm 0.4$ & $13.7 \pm 0.2$ & $169 \pm 4$ & $12.1 \pm 0.1$ & 13.7 & 5.9 & 154 & 13.5 \\
\hline Campalto/48 & 20.7 & $12.7 \pm 0.3$ & $14.2 \pm 0.1$ & $167 \pm 1$ & $12.2 \pm 0.1$ & 13.4 & 5.8 & 139 & 13.5 \\
\hline Campalto/60 & 24.2 & $19.7 \pm 0.2$ & $14.2 \pm 0.1$ & $106 \pm 2$ & $12.4 \pm 0.1$ & 13.5 & 5.9 & 94 & 13.2 \\
\hline
\end{tabular}
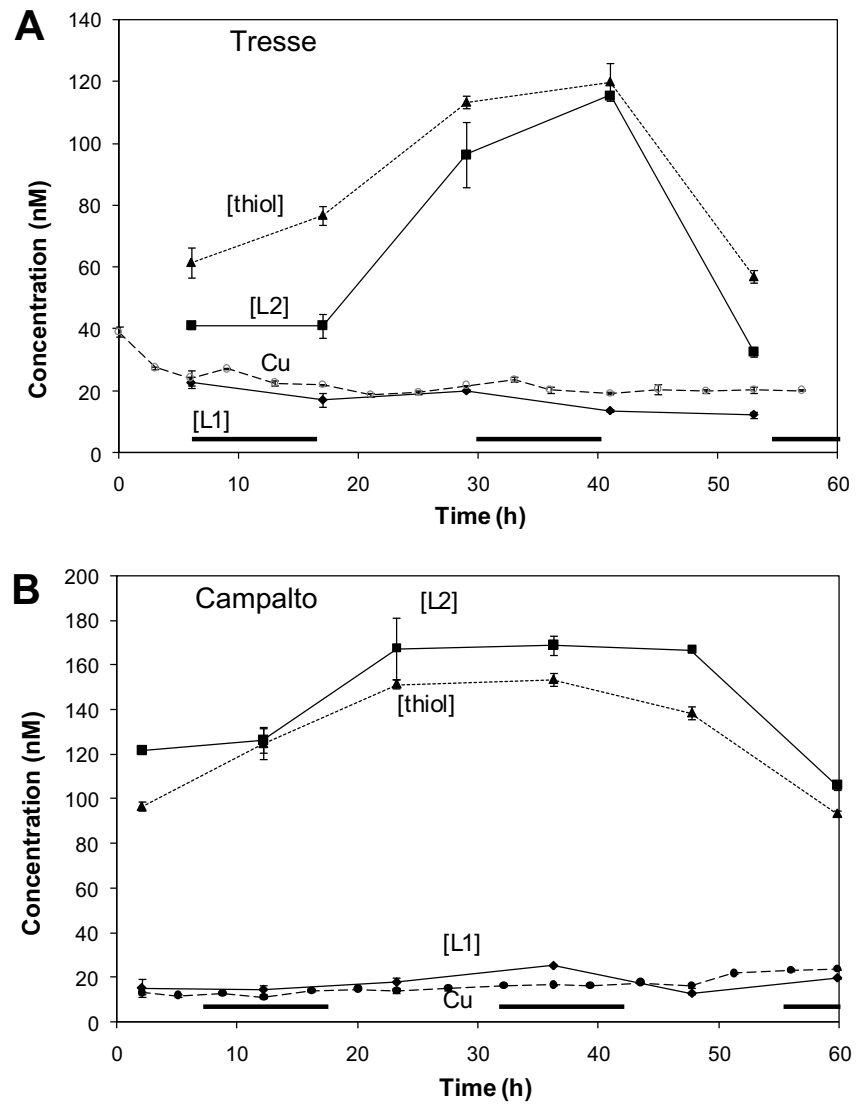

Fig. 4. Changes in the concentrations of copper, ligands and thiols (glutathione equivalents) as a function of time in the benthic chambers at Tresse (A) and Campalto (B). Mean and standard deviation values are shown for three repeated analyses are shown.

The concentration of $\mathrm{L} 1$ was on average $17 \pm 4 \mathrm{nM}$ at the two stations, much less than that $(108 \pm 51 \mathrm{nM})$ of L2 (Fig. 4). During the titrations L1 became saturated and subsequent copper additions were bound to the weaker ligand (L2). The change in the slope (indicating saturation of L1) occurred at $\mathrm{pCu} \sim 13.1$ at both stations. Due to the higher copper concentrations at the start of the Tresse experiment, L1 was largely saturated and L2 bound there more copper (up to 50\%) than at Campalto. The difference between the complex stability of L1 and L2 was 1.7 log-units, indicating that L1 and L2 are of a different nature or that different sites are responsible for copper complexation.

The equilibrium concentration of copper at $\sim 19-22 \mathrm{nM}$ at both sites was similar to that of L1, suggesting that this ligand may play an important role in keeping copper at a level approximately equal to its concentration. Possibilities are that copper-complexed L1 is stabilized from photochemical (Laglera and van den Berg, 2006), or bacterial breakdown, or because copper-L1 species are released from porewaters, or a combination of these.

The concentration of L2 was much greater than that of copper. Because L2 forms weaker complexes with copper than L1, L2 played a secondary role with respect to copper complexation in these waters in spite of its higher concentration, whereas L1 was generally fully complexed with copper. During the incubation in the chambers the concentration of L2 increased from 40 to $120 \mathrm{nM}$ at Campalto, and from 120 to $160 \mathrm{nM}$ at Tresse, as a result of diffusion from the sediments as will be shown below, before dropping back to the original level near the end of the experiment, probably due to photodegradation.

There is no previous published work on the chemical speciation of copper in this lagoon. The ligand concentrations and complex stability are similar to those in estuarine waters or productive shelf waters, but greater than those expected for deeper coastal waters. For instance at the higher salinity end of the estuary of the river Scheldt the concentration of L1 was $12.9 \mathrm{nM}$ with a complex stability of $\log \mathrm{K}_{\text {CuL1 }}^{\prime}=14.8$ (Laglera and van den Berg, 2003); the concentration of L2 in that water was $35 \mathrm{nM}$ with a value for log $\mathrm{K}_{\text {CuL2 }}^{\prime}$ of 13.2. Guanabara Bay, a shallow lagoon adjacent to Rio de Janeiro, had copper complexing ligands at greater concentrations of $40-300 \mathrm{nM}$ and $\log \mathrm{K}_{\mathrm{CuL}}$ values of 9.6 to 12.4 (Van Den Berg and De Luca Rebello, 1986). These results are directly comparable as they had been determined at a similar detection window but using a different ligand (catechol) as competing ligand. The much greater ligand concentrations in Guanabara Bay were likely caused by a high primary productivity. Complex stabilities of log $\mathrm{K}_{\text {CuL1 }}^{\prime}>12.5$ have been reported for Gullmar Fjord, Sweden (Croot, $2003)$, and of $\log K_{\text {CuL1 }}^{\prime}>13.5$ and $\log K_{\text {CuL2 }}^{\prime}$ of $9.0-9.6$ in waters of San Francisco Bay (Donat et al., 1994). The complex stabilities cover therefore several log-units, and the ligand concentrations several decades, in near coastal or estuarine waters. Part of the reason for this variability may be that the analytical methods have difficulties in discriminating between the ligands, but at the same time it is likely that several ligands are present and that competition reactions with other metals can cause the complex stabilities to vary.

\subsection{Thiols as a candidate for the natural ligands}

Thiol compounds are known to form strong complexes with copper (Leal and van den Berg, 1998) and have been shown to exist in estuarine waters (Laglera and van den Berg, 2003; Tang et al., 2000) and salt marsh sediments (Luther III et al., 1986). For this reason a method (Laglera and van den Berg, 2003) was used in this work that identifies thiol-type ligands directly from their specific 
voltammetric response. The thiol peak was apparent in the voltammetric scans of all the samples of this study, in the potential range between -0.55 and $-0.65 \mathrm{~V}$, typical for thiols (Al-Farawati and Van Den Berg, 2001; Leal and Van den Berg, 1998), and sulphide species (Rozan et al., 2000). Stability of the peak indicated that the response was due to thiols, as the sulphide peak is known to be unstable, except at very high concentration, decreasing rapidly in height due to reaction with mercury traces in the voltammetric cell (Al-Farawati and van den Berg, 1997). The sensitivity was calibrated with glutathione which matched the electrochemical characteristics of the peak with respect to peak potential and shape and its response at different deposition potentials. Copper additions caused the thiol peak to decrease and shift to a more negative potential (Fig. $5 \mathrm{~A}$ ) due to a change from a mercury-thiol species to a copper-thiol species on the surface of the electrode with increasing copper concentration (Le Gall and van den Berg, 1993):

HgThiol $_{\mathrm{ads}}+\mathrm{CuSA}+2 \mathrm{e}^{-} \rightarrow$ CuThiol $_{\mathrm{ads}}+\mathrm{Hg}+\mathrm{SAH}$

Copper-binding thiol concentrations and values for their complex stability ( $\mathrm{K}^{\prime}$ CuThiol $)$ were determined by fitting the voltammetric thiol response to the free, $\mathrm{Cu}^{2+}$, concentration obtained during the copper complexing capacity titrations (Laglera and van den Berg, 2003) and are shown in Table 1.

The total thiol concentrations were determined by adding EDTA $\left(100 \mu \mathrm{M}, \log \alpha_{\text {CuEDTA }}=6\right)$ to each sample to mask ambient
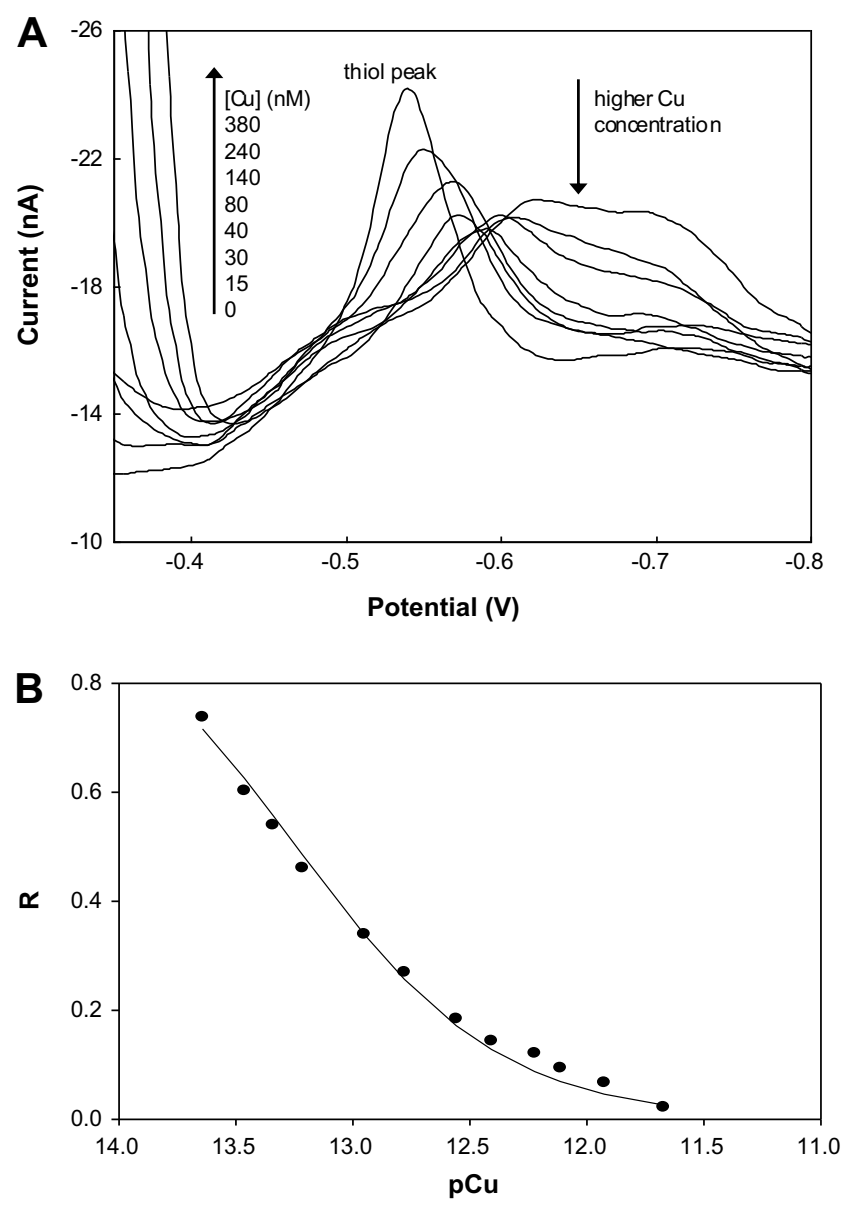

Fig. 5. Effect of varying the copper concentration on the response for the thiol species. (A) CSV scans for copper and thiols in Lagoon water showing the decrease in the thiol peak (which is an Hg-thiol species) as the copper-SA peak increases; the copper-SA peak is off scale at $-0.35 \mathrm{~V}$; (B) change in the thiol peak height ( $R=$ relative peak height $\left.=i_{\mathrm{p}} / i_{\mathrm{pmax}}\right)$ as a function of $\mathrm{pCu}$ showing that the thiols started to bind copper from $\mathrm{pCu} \sim 14$, becoming saturated at $\mathrm{pCu} \sim 12.5$. Individual $\mathrm{pCu}$ values were calculated from $\left[\mathrm{Cu}_{\text {reactive }}\right] / \alpha_{\text {CuSA. }}$. copper from the thiol to obtain the overall thiol peak current $\left(I_{\max }\right)$, where the $\alpha$-coefficient indicates the ratio of complexed over free copper $\left([\mathrm{CuEDTA}] /\left[\mathrm{Cu}^{2+}\right]\right)$. The EDTA addition was found to increase the reactive thiol concentration by $20-25 \%$ compared to that in the presence of $10 \mu \mathrm{M} \mathrm{SA}\left(\log \alpha_{\mathrm{CuSA}} \sim 5\right)$ in line with expectation for a high complex stability of the thiol species. The CSV scans for the total thiol determinations were similar to the scan shown at the lowest copper concentration in Fig. 5A, but then with a smaller peak height for copper and a greater peak height for the thiol.

Plots of $I_{p} / I_{\max }$ showed that the thiol compounds started to bind copper at $10^{-14} \mathrm{Cu}^{2+}$ and were saturated at $10^{-12} \mathrm{M} \mathrm{Cu}^{2+}$ consistent with a value for $\log K_{\text {Cuthiol }}^{\prime}$ near 13 (Fig. 5 B). The fitted $\log K_{\text {Cuthiol }}^{\prime}$ values were similar at the two study sites with an average of $13.1 \pm 0.2$. The complex stability of the copper thiols is near that of the CuL2 species $\left(\log K_{\text {CuL2 }}^{\prime}=12.5 \pm 0.3\right)$. The alpha-coefficient for copper binding by the thiols, $\alpha_{\mathrm{Cu}-\text { thiol }}=[\mathrm{CuThiol}] /\left[\mathrm{Cu}^{2+}\right]$, was $\sim 10^{6.1}$ (for $100 \mathrm{nM}$ thiols with average complex stability), compared to a value of $\alpha_{\mathrm{CuL} 2}=10^{5.5}$ for $100 \mathrm{nM}$ of L2 and $\alpha_{\mathrm{CuL} 1}=$ $10^{6.5}$ for $20 \mathrm{nM}$ of $\mathrm{L} 1$. The higher value for $\mathrm{Cu}^{2+}$ complexation with L1 is due to the high stability of the L1 species, but it does not reflect that L1 is mostly saturated with copper causing any excess copper to be bound with L2.

\subsection{Identification and quantification of the thiol compounds}

The CSV response of the thiols in Venice Lagoon was compared to that of several thiols (thioacetamide, thiourea, cysteine and glutathione) and glutathione was found to give a good match. $100 \mathrm{nM}$ additions caused a small $10 \mathrm{mV}$ negative shift in peak position and a slight broadening of the peak. The thiol peak height is known to be dependent on $\mathrm{pH}$, deposition potential as well as on concentration (Laglera and van den Berg, 2003; Le Gall and van den Berg, 1993) so this shift was not unusual. The CSV response for the thiols in Venice Lagoon varied upon variation of the deposition potential similarly to that of glutathione, with a much smaller change in response than for thiourea or thioacetamide consistent with a response due to mercury species typical for glutathione ( $\mathrm{Hg}$ (II)glutathione) (Leal and Van den Berg, 1998). Because of its similar response characteristics, glutathione was used to calibrate the sensitivity for the thiol determinations.

\subsection{Fluxes of thiols from the benthic chamber data}

Thiol concentrations in the chambers at both sites were found to initially increase with time and subsequently decrease after about $40 \mathrm{~h}$. At Tresse the thiols increased from $60 \mathrm{nM}$ to $120 \mathrm{nM}$ (glutathione equivalents) (see Fig. 6), and at Campalto from 100 to 160 , so the overall increase was the same magnitude. The thiol concentration in the external water was $40 \mathrm{nM}$ at Tresse and $110 \mathrm{nM}$ at Campalto. The average thiol fluxes were $63 \pm 1 \mathrm{pmol} \mathrm{cm}^{-2} \mathrm{~h}^{-1}$ at Campalto and $51 \pm 1 \mathrm{pmol} \mathrm{cm}^{-2} \mathrm{~h}^{-1}$ at Tresse for the first $25 \mathrm{~h}$ of the experiment. The decreasing thiol concentrations at the end of the experiment may be due to activities of suspended or benthic organisms, or to photochemical breakdown as the chamber was exposed to sunlight in these very shallow waters and as thiols and other ligands are known to be liable to photochemical breakdown (Laglera and van den Berg, 2006; Shank et al., 2006). Biological breakdown may also have played a role as thiols are a known substrate for marine bacteria (Tripp et al., 2008; Visscher and Taylor, 1993), phytoplankton (Ietswaart et al., 1994) and the microphytobenthic community generally (Linares and Sundback, 2006).

\subsection{Thiols in the sedimentary porewaters}

The thiol concentrations $(60-170 \mathrm{nM})$ during these benthic chamber experiments were much greater than those (0.7- 

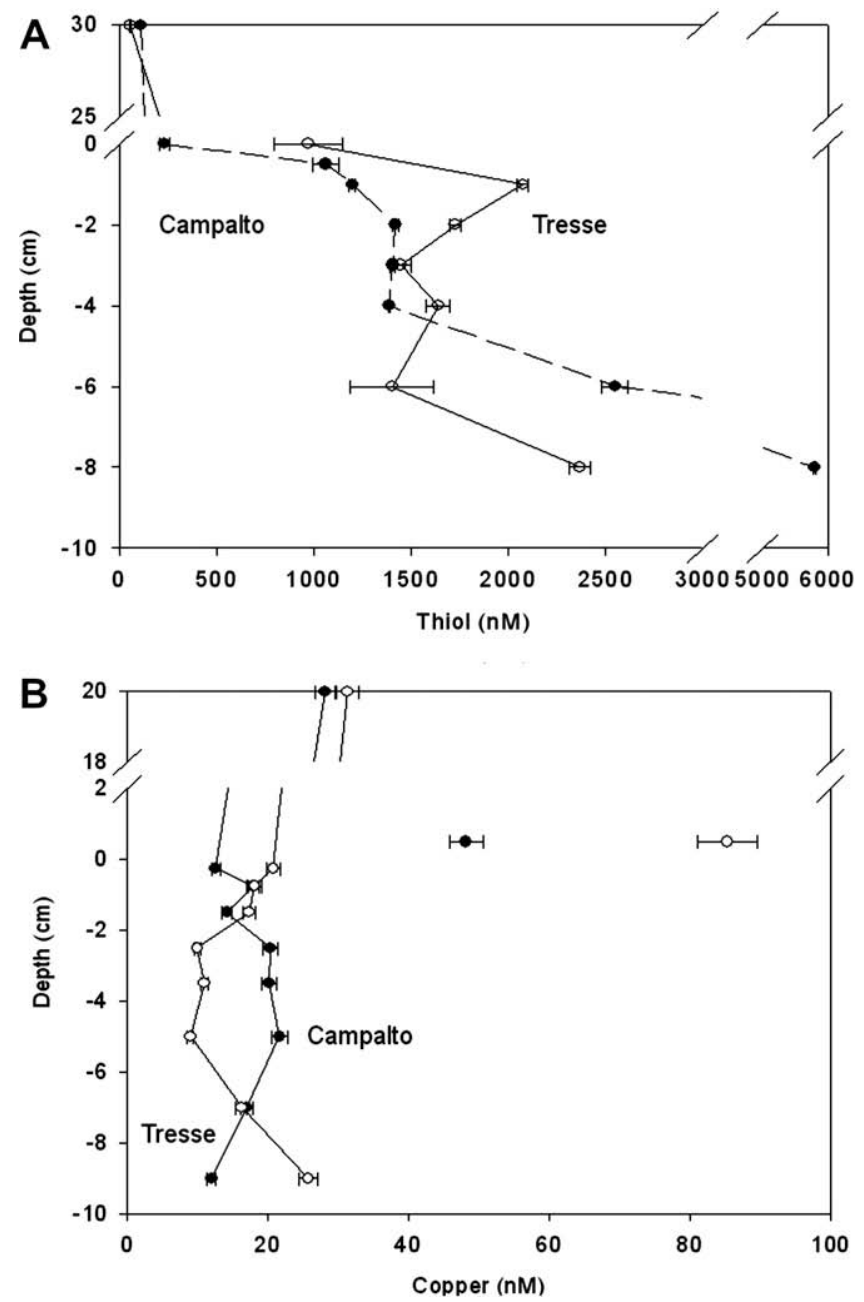

Fig. 6. Concentrations of dissolved thiols (glutathione equivalents) (A) and copper (B) in porewaters from sediment cores taken at the study sites. Mean values and standard deviations for 3 repeated analyses are shown $(n=3)$.

3.6 $\mathrm{nM}$ ) typical for the deeper coastal waters of the North Sea (Al-Farawati and Van Den Berg, 2001). In view of the similar increase in both chambers it is likely that benthic processes are the source of the much greater thiol concentrations in these marsh waters. For this reason porewaters were subsampled from sediment box-cores at the experimental sites. The cores were collected about 2 weeks after the benthic chamber experiment, but this should not affect the basic findings as the benthic processes are established over long time scales.

The porewaters were found to contain extremely high (micromolar) thiol concentrations $(1.2 \mu \mathrm{M}$ at a depth of $2 \mathrm{~cm}, 6 \mu \mathrm{M}$ at $8 \mathrm{~cm})$ much greater than in the overlying waters $(\sim 100 \mathrm{nM})$ (Fig. 4). The large difference explains that the high apparent thiol flux in the benthic chamber could easily have originated from the sediments, not from in situ production in the chamber. The thiol identity (similar to glutathione as based on the electrochemical characteristics) was the same in the porewaters as in the overlying water, confirming that the porewater thiols are the source of the thiols in the overlying water.

The porewater concentrations of the thiols increase with depth, which is consistent with an in situ production by reaction of sulfide with sedimentary organic matter (Vairavamurthy and Mopper, 1987). Similar trends but at higher levels (0.1-2.5 mM organic thiol) have been observed previously in salt-marsh porewaters (Luther III et al., 1986). Our benthic chamber experiments demon-
Table 2

The measured flux $\left(\mathrm{F}_{\mathrm{m}}\right.$ in pmol $\left.\mathrm{cm}^{-2} \mathrm{~h}^{-1}\right)$ from the benthic chamber data and the modelled diffusion flux $\left(F_{d}\right.$ in pmol $\left.\mathrm{cm}^{-2} \mathrm{~h}^{-1}\right)$ from porewater data. Diffusion coefficients used for the calculation: thiol: $14.8 \times 10^{-6} \mathrm{~cm}^{2} \mathrm{~s}^{-1}$ and copper: $7.3 \times 10^{-6} \mathrm{~cm}^{2} \mathrm{~s}^{-1}$. The values shown are the mean \pm SD for 3 repeated analyses.

\begin{tabular}{lllll}
\hline & Thiol & \multicolumn{3}{c}{ Copper } \\
\hline Site name & Tresse & Campalto & Tresse & Campalto \\
$\mathrm{F}_{\mathrm{m}}$ & $51 \pm 1$ & $63 \pm 1$ & $-4.4 \pm 0.2$ & $3.8 \pm 0.1$ \\
$\mathrm{~F}_{\mathrm{d}}$ & $344 \pm 2$ & $84 \pm 8$ & $-2.1 \pm 0.1$ & $-3.8 \pm 0.2$
\end{tabular}

strate that the porewaters are the main source of thiols in the overlying waters, and that the steady state level of thiols is a balance of porewater releases and biological uptake and photochemical reactions in the surface waters.

Porewater fluxes were estimated from the concentration difference between the top of the porewaters and the overlying waters (Table 2). These thiol fluxes are much greater than those from the benthic chamber data ( $7 \mathrm{x}$ at Tresse and $1.3 \mathrm{x}$ at Campalto), suggesting that there is a rapid loss of the thiols in the overlying water, which may be due to rapid uptake by microorganisms, or photolysis, of the thiols. It is also possible that a benthic boundary diffusive sublayer (Morse, 1974; Sundby et al., 1986) inhibited transport from the benthic interface to the overlying water.

Although the gradient in the sediment core itself is evidence for an outward flux, the calculation of the magnitude of the flux is subject to large uncertainty due to the difficulty of finding the thiol concentration at the surface of the sediments which is responsible for the flux into the overlying water in case of a steep gradient inside the sediment. The difference in the thiol fluxes at Tresse and Campalto is probably due to this uncertainty, so the best we can establish from the porewater data is a) that the porewaters are a source of thiols to the overlying waters because the porewater thiol concentration is much greater than in the overlying water, and $b$ ) that the flux must be large in view of the large gradient in the sediments and because of the concentration difference with the overlying water.

The porewater concentration of copper of $16-20 \mathrm{nM}$ (Fig. 4B) was similar to or slightly less than in the overlying water in the benthic chambers, except for high values ( $83 \mathrm{nM}$ at Tresse and $47 \mathrm{nM}$ at Campalto) at the sediment surface (this had been sampled separately using an in situ pump, close to the sediment surface). The porewater concentrations are similar to those found in other coastal sediments (Ciceri et al., 1992; Westerlund et al., 1986). The much greater levels at the sediment surface are possibly associated with a fluffy layer of organic-rich material (Hlawatsch et al., 2002) enriched in copper, which could have been sucked up into the sampling tube. These high values were not used for the porewater flux calculations as it is likely that this copper was not free but associated with flocs of organic matter, but they are of interest as it illustrates the variability at the sediment surface. The lack of a clear gradient in the sediments suggests that any copper flux into, or out of the overlying waters is small. Any copper diffusing out of, or into these sediments would have to pass through, and could be trapped by, this fluffy layer. It will be interesting to investigate the copper speciation exactly at the interface in further work, as stabilization of copper at this location, rather than the deeper porewater concentration, could control the copper concentration in the overlying waters.

\section{Acknowledgments}

This work was financially supported by the Consortium for Coordination of Research Activities concerning the Venice Lagoon System (CORILA, Venice, Italy), and sponsorship of Chapman by 
the Leverhulme Trust. The authors are grateful to M. Frignani for the porosity data, Luis M. Laglera for assistance with data fitting, and anonymous referees for constructive comments.

\section{References}

Al-Farawati, R., van den Berg, C.M.G., 1997. The determination of sulfide in seawater by flow-analysis with voltammetric detection. Marine Chemistry 57, 277286.

Al-Farawati, R., Van Den Berg, C.M.G., 2001. Thiols in coastal waters of the western North Sea and English Channel. Environmental Science and Technology 35, 1902-1911.

Berner, R.A., 1980. A Theoretical Approach, Early Diagenesis,. Princeton University Press, Princeton. pp. 236.

Brand, L.E., Sunda, W.G., Guillard, R.R.L., 1986. Reduction of marine-phytoplankton reproduction rates by copper and cadmium. Journal of Experimental Marine Biology and Ecology 96, 225-250.

Campos, M.L.A.M., van den Berg, C.M.G., 1994. Determination of copper complexation in sea water by cathodic stripping voltammetry and ligand competition with salicylaldoxime. Analytica Chimica Acta 284, 481-496.

Ciceri, G., Maran, S., Martinotti, W., Queirazza, G., 1992. Geochemical Cycling of Heavy-Metals In A Marine Coastal Area - Benthic Flux Determination From Pore Water Profiles And Insitu Measurements Using Benthic Chambers. Hydrobiologia 235, 501-517.

Clavero, V., Fernandez, J.A., Niell, F.X., 1992. Bioturbation by Nereis Sp and Its Effects on the Phosphate Flux across the Sediment-Water Interface in the Palmones River Estuary. Hydrobiologia 235, 387-392.

Cochran, J.K., Frignani, M., Salamanca, M., Bellucci, L.G., Guerzoni, S., 1998. Lead-210 as a tracer of atmospheric input of heavy metals in the northern Venice Lagoon. Marine Chemistry 62, 15-29.

Croot, P.L., 2003. Seasonal cycle of copper speciation in Gullmar Fjord, Sweden. Limnology and Oceanography 48, 764-776.

Croot, P.L., Moffett, J.W., Brand, L.E., 2000. Production of extracellular Cu complexing ligands by eucaryotic phytoplankton in response to $\mathrm{Cu}$ stress. Limnology and Oceanography 45, 619-627.

Donat, J.R., Lao, K.A., Bruland, K.W., 1994. Speciation of dissolved copper and nickel in South San Francisco Bay: a multi-method approach. Analytica Chimica Acta 284, 547-571.

Donazzolo, R., Orio, A.A., Pavoni, B., Perin, G., 1984. Heavy-metals in sediments of the Venice Lagoon. Oceanologica Acta 7, 25-32.

Dupont, C.L., Ahner, B.A., 2005. Effects of copper, cadmium, and zinc on the production and exudation of thiols by Emiliania huxleyi. Limnology and Oceanography 50, 508-515.

Dupont, C.L., Moffett, J.W., Bidigare, R.R., Ahner, B.A., 2006. Distributions of dissolved and particulate biogenic thiols in the subartic Pacific Ocean. DeepSea Research Part I-Oceanographic Research Papers 53, 1961-1974.

Fernandes, H.M., Bidone, E.D., Veiga, L.H.S., Patchineelam, S.R., 1994. Heavy-Metal Pollution Assessment In The Coastal Lagoons Of Jacarepagua, Rio-De-Janeiro, Brazil. Environmental Pollution 85, 259-264.

Hlawatsch, S. et al., 2002. Fast-growing, shallow-water ferro-manganese nodules from the western Baltic Sea: origin and modes of trace element incorporation. Marine Geology 182, 373-387.

Ietswaart, T., Schneider, P.J., Prins, R.A., 1994. Utilization of Organic NitrogenSources by 2 Phytoplankton Species and a Bacterial Isolate in Pure and Mixed Cultures. Applied and Environmental Microbiology 60, 1554-1560.

Iversen, N., Jorgensen, B.B., 1993. Diffusion-coefficients of sulfate and methane in marine-sediments-influence of porosity. Geochimica Et Cosmochimica Acta 57, 571-578.

Klinkhammer, G., 1980. Early diagenesis in sediment from the eastern equatorial Pacific, II, Pore water metal results. Earth and Planetary Science Letters 49, 81101

Laglera, L.M., van den Berg, C.M.G., 2003. Copper complexation by thiol compounds in estuarine waters. Marine Chemistry 82, 71-89.

Laglera, L.M., van den Berg, C.M.G., 2006. Photochemical oxidation of thiols and copper complexing ligands in estuarine waters. Marine Chemistry 101, 130140.

Le Gall, A.-C., van den Berg, C.M.G., 1993. Cathodic stripping voltammetry of glutathione in natural waters. Analyst 118, 1411-1415.

Le Gall, A.-C., van den Berg, C.M.G., 1998. Folic acid and glutathione in the water column of the North East Atlantic. Deep-Sea Research Part I-Oceanographic Research Papers 45, 1903-1918.
Leal, M.F.C., Van den Berg, C.M.G., 1998. Evidence for strong copper(I) complexation by organic ligands in seawater. Aquatic Geochemistry 4, 49-75.

Leal, M.F.C., Vasconcelos, M.T.S.D., van den Berg, C.M.G., 1999. Copper-induced release of complexing ligands similar to thiols by Emiliania huxleyi in seawater cultures. Limnology and Oceanography 44, 1750-1762.

Li, Y.H., Gregory, S., 1974. Diffusion coefficients of ions in seawater and in deep-sea sediments. Geochimica Cosmochimica Acta 38, 703-714.

Linares, F., Sundback, K., 2006. Uptake of dissolved free amino acids (DFAA) by microphytobenthic communities. Aquatic Microbial Ecology 42, 175-186.

Luther III, G.W., Church, T.M., Scurdlark, J.R., Cosman, M., 1986. Inorganic and organic sulfur cycling in salt marsh pore waters. Science 232, 746-749.

Manodori, L. et al., 2006. PCBs and PAHs in sea-surface microlayer and sub-surface water samples of the Venice Lagoon (Italy). Marine Pollution Bulletin 52, 184 192.

Martin, J.M., Huang, W.W., Yoon, Y.Y., 1994. Level and fate of trace metals in the lagoon of Venice (Italy). Marine Chemistry 46, 371-386.

Moffett, J.W., Brand, L.E., 1996. Production of strong, extracellular Cu chelators by marine cyanobacteria in response to Cu stress. Limnology and Oceanography $41,388-395$.

Morse, J.W., 1974. Calculation of Diffusive Fluxes across Sediment-Water Interface. Journal of Geophysical Research 79, 5045-5048.

Pavoni, B., Donazzolo, R., Marcomini, A., Degobbis, D., Orio, A.A., 1987. Historical development of the Venice Lagoon contamination as recorded in radiodated sediment cores. Marine Pollution Bulletin 18, 18-24.

Rozan, T.F., Theberge, S.M., Luther III, G.W., 2000. Quantifying elemental sulfur (S-0), bisulfide (HS-) and polysulfides (S-x(2-)) using a voltammetric method. Analytica Chimica Acta 415, 175-184.

Shank, G.C., Whitehead, R.F., Smith, M.L., Skrabal, S.A., Kieber, R.J., 2006. Photodegradation of strong copper-complexing ligands in organic-rich estuarine waters. Limnology and Oceanography 51, 884-892.

Skrabal, S.A., Donat, J.R., Burdige, D.J., 2000. Pore water distributions of dissolved copper and copper- complexing ligands in estuarine and coastal marine sediments. Geochimica Et Cosmochimica Acta 64, 1843-1857.

Sundby, B. et al., 1986. The effect of oxygen on release and uptake of cobalt manganese, iron and phosphate at the sediment-water interface. Geochimica et Cosmochimica Acta 50, 1281-1288.

Tang, D.G., Hung, C.C., Warnken, K.W., Santschi, P.H., 2000. The distribution of biogenic thiols in surface waters of Galveston Bay. Limnology and Oceanography 45, 1289-1297.

Tang, D.G., Shafer, M.M., Karner, D.A., Overdier, J., Armstrong, D.E., 2004. Factors affecting the presence of dissolved glutathione in estuarine waters. Environmental Science and Technology 38, 4247-4253.

Tengberg, A., Hall, P.O.J., Andersson, U., Linden, B., Styrenius, O., Boland, G., De Bovee, F., Carlsson, B., Ceradini, S., Devol, A., Duineveld, G., Friemann, J.U., Glud, R.N., Khripounoff, A., Leather, J., Linke, P., Lund-Hansen, L., Rowe, G., Santschi, P., De Wilde, P., Witte, U., 2005. Intercalibration of benthic flux chambers: II Hydrodynamic characterization and flux comparisons of 14 different designs. Marine Chemistry 94, 147-173.

Tripp, H.J. et al., 2008. SAR11 marine bacteria require exogenous reduced sulphur for growth. Nature 452, 741-744.

Turetta, C., Capodaglio, G., Cairns, W., Rabar, S., Cescon, P., 2005. Benthic fluxes of trace metals in the lagoon of Venice. Microchemical Journal 79, 149-158.

Turoczy, N.J., Sherwood, J.E., 1997. Modification of the van den Berg/Ruzic method for the investigation of complexation parameters of natural waters. Analytica Chimica Acta 354, 15-21.

Vairavamurthy, A., Mopper, K., 1987. Geochemical formation of organosulfur compounds (thiols) by addition of H2S to sedimentary organic-matter. Nature 329, 623-625.

Van Den Berg, C.M.G., De Luca Rebello, A., 1986. Organic-copper interactions in Guanabara Bay, Brazil, an electrochemical study of copper complexation by dissolved organic material in a tropical bay. Science of the Total Environment 58, 37-45.

Vazquez, G.F. et al., 1999. Metal ions in water and sediments of the Pom-Atasta Lagoon, Mexico. Environment International 25, 599-604.

Visscher, P.T., Taylor, B.F., 1993. Organic thiols as organolithotrophic substrates for growth of phototrophic bacteria. Applied and Environmental Microbiology 59, 93-96.

Westerlund, S.F.G. et al., 1986. Benthic Fluxes of Cadmium, Copper, Nickel, Zinc and Lead in the Coastal Environment. Geochimica Et Cosmochimica Acta 50, 12891296.

Zirino, A., VanderWeele, D.A., Belli, S.L., DeMarco, R., Mackey, D.J., 1998. Direct measurement of $\mathrm{Cu}(\mathrm{II})(\mathrm{aq})$ in seawater at $\mathrm{pH} 8$ with the jalpaite ion-selective electrode. Marine Chemistry 61, 173-184. 